\title{
Peran Manajemen Laba Memediasi Hubungan Antara CSR, GCG Dan Kinerja Perusahaan Keluarga
}

\author{
Iskandar Itan \\ Universitas Internasional Batam, iskandar@uib.ac.id
}

\begin{abstract}
ABSTRAK
Penelitian ini bertujuan untuk mengetahui peran mediasi manajemen laba antara corporate social responsibility $(C S R)$, good corporate governance $(G C G)$ dan kinerja perusahaan pada perusahaan keluarga. Penelitian ini menggunakan pendekatan data panel dengan 116 perusahaan keluarga yang listed di Bursa Efek Indonesia dijadikan sampel penelitian untuk periode 2014 hingga 2018 dan dianalisis dengan SPSS dan Smart PLS 3.0. Dalam penelitian ini, CSR diukur dengan indeks ISO 26000 dan GCG diukur berdasarkan dewan direksi, komisaris independen, dewan komisaris dan kualitas audit, sedangkan kinerja perusahaan diukur dengan return on asset (ROA), Tobin's Q serta earning per share (EPS). Sementara itu, manajemen laba diukur dengan menggunakan discretionary accruals (DA) model Jones yang di-modifikasi. Hasil penelitian menunjukkan bahwa CSR dan GCG dapat memberikan citra positif terhadap kinerja perusahaan. Hasil ini juga menunjukkan bahwa manajemen laba mempunyai peran mediasi atas hubungan antara GCG dan kinerja perusahaan tetapi gagal memediasi hubungan antara CSR dan kinerja perusahaan.
\end{abstract}

Kata Kunci: Corporate Social Responsibility, Good Corporate Governance, Manajemen Laba, Kinerja Perusahaan, Perusahaan Keluarga

\begin{abstract}
This study looks into the mediating role of earning management on the relationship between corporate social responsibility (CSR), good corporate governance (GCG) and family-owned companies' performance. This study uses the panel data approach, and 116 family-owned companies on Indonesia Stock Exchange are included as the sample for the period 2014 to 2018 and data were analysed using SPSS and Smart PLS 3.0 software. In this study, CSR is measured using index of ISO 26000, good corporate governance is measured by board size, independent commissioners, board of commissioners and audit quality, while firm performance is measured by return on asset (ROA), Tobin's $Q$ and earning per share (EPS). Meanwhile, earning management is measured using discretionary accruals (DA) with the modified Jones model. The results show that CSR and GCG can build positive impact on firm performance. The findings also show that earning management mediates the relationship between GCG and firm performance, while it failed to mediate the relationship between CSR and firm performance.
\end{abstract}

Keywords: Corporate Social Responsibility, Corporate Governance, Earning Management, Firm Performance, Family-owned Companies

Naskah diterima: 28-08-2020, direvisi: 01-07-2020, diterbitkan: 01-09-2020

ISSN: 2355-0295, e-ISSN: 2549-8932 


\section{PENDAHULUAN}

Seiring meningkatnya perang dagang antara Amerika Serikat dan Tiongkok, banyak perusahaan multinasional memindahkan perusahaan mereka dari Tiongkok ke negara lain untuk bertahan dalam ketegangan perdagangan ini (Kompas, 2019). Menurut Nikkei Asian Review, beberapa perusahaan yaitu Google, Nintendo dan Dell menghindari tarif impor yang tinggi yang dikenakan pada produk-produk dari Tiongkok senilai 250 miliar dolar AS. Salah satu perusahaan raksasa Jepang, Nintendo telah memindahkan manufaktur perangkat switch-nya dari Tiongkok ke Vietnam karena potensi kenaikan tarif pada barang yang diproduksi di Tiongkok. Sementara perusahaan Google, Alphabet Inc. telah mengalihkan banyak produksinya seperti motherboard ke Taiwan, untuk menghindari tarif 25\% (Kompas, 2019).

Dalam ketegangan perdagangan yang berdampak pada pertumbuhan ekonomi, perusahaan keluarga telah memainkan peran penting, terutama untuk mendorong pertumbuhan ekonomi keuangan negara dengan meningkatkan Produk Nasional Bruto (Yopie \& Itan, 2016) . Keadaan bisnis internasional yang dinamis dan terus berubah telah memaksa investor untuk ber-intraksi dengan bisnis milik keluarga. Perusahaan keluarga memiliki kontribusi positif untuk memulihkan keadaan ekonomi nasional terlihat dari beberapa perusahaan Indonesia yang telah selamat dan melewati masa krisis ekonomi pada tahun 1998 dan 2008. Oleh karena itu, salah satu kunci untuk mendukung perusahaan-perusahaan ini adalah melaksanakan good corporate governance (GCG) dengan baik (Yopie \& Itan, 2016). GCG merupakan struktur, system dan proses yang digunakan perusahaan untuk meningkatkan value added perusahaan secara terus menerus.

GCG telah menerima begitu banyak perhatian dari akademisi. GCG adalah fondasi yang kokoh dalam mengelola bisnis dan faktor kunci yang dapat meningkatkan pertumbuhan value perusahaan yang dikendalikan keluarga. GCG memiliki berbagai tata cara dan tindakan untuk menyelesaikan masalah dan penyelesaian masalah perusahaan biasanya diputuskan berdasarkan keputusan oleh pemegang saham pengendali atau yang terbesar (Yopie \& Itan, 2016). Di Indonesia, salah satu pemegang saham terbesar dalam perusahaan adalah keluarga.

Dalam menjalankan aktivitasnya, selain memenuhi kepentingan pemegang saham, perusahaan juga harus memenuhi kepentingan pemangku kepentingan lainnya (stakeholders). Salah satu kebijakan perusahaan adalah menjalankan program CSR secara konsisten. CSR telah memberikan nilai tambah pada perusahaan atas kinerja perusahaan. Kegiatan CSR memastikan kegiatan operasional perusahaan diterima oleh masyarakat lokal (Deegan et al., 2002).

Banyak peneliti yang telah menyelidiki hubungan antara CSR, GCG dan kinerja perusahaan, tetapi hanya beberapa yang menggunakan variable mediasi manajemen laba, terutama terhadap kinerja perusahaan pada perusahaan milik keluarga.

Merujuk uraian di atas, tujuan penelitian ini adalah untuk mengetahui peran mediasi manajemen laba pada hubungan antara CSR, GCG dan kinerja perusahaan pada perusahaan keluarga.

\section{KAJIAN LITERATUR}

Jensen \& Meckling (1976) menjelaskan bahwa teori keagenan adalah hubungan yang terjadi antara agen yang berfungsi sebagai pengelola perusahaan dan prinsipal. Agen akan diberi wewenang dan harus mengambil keputusan terbaik untuk perusahaan dan menunjukkan kinerja yang baik bagi prinsipal. Tujuan teori keagenan adalah untuk memenuhi keinginan perusahaan dalam memaksimalkan dan meningkatkan nilai pemegang saham (Jensen \& Meckling, 1976). Sementara itu, sebagaimana dinyatakan oleh Parmar et al. (2010), teori pemangku kepentingan (stakeholder theory) berfokus pada nilai dan moral dalam mengelola organisasi bisnis. Kehadiran stakeholders sangat penting untuk menjalankan kegiatan perusahaan karena membantu perusahaan untuk fokus pada kepentingan semua stakeholders, bukan hanya kepada pemegang saham (Harrison \& Wicks, 2013). Kepentingan stakeholder akan dipengaruhi oleh kegiatan dan pencapaian perusahaan, 
seperti program CSR yang konsisten dan baik serta kinerja perusahaan. CSR merupakan konsep atau kegiatan yang dilaksanakan perusahaan sebagai bentuk tanggung jawab terhadap kondisi lingkungan serta masyarakat yang bernaung di sekitar perusahaan beroperasi. Hal ini didasarkan pada kesadaran perusahaan akan penting nya keberlanjutan perusahaan daripada sekedar laba perusahaan. Implementasi GCG dengan baik dapat memastikan bahwa investasi yang ditanamkan oleh para investor di perusahaan digunakan sebagaimana mestinya dan efisien. Selain itu, GCG dapat mengarah pada kinerja yang efektif dan lebih baik dalam perusahaan (Mahrani \& Soewarno, 2018). Perusahaan yang memiliki komitmen kuat terhadap penerapan GCG dapat meningkatkan citra perusahaan serta memberikan kinerja yang baik bagi perusahaan dan memberikan manfaat bagi para stakeholders. Oleh karena itu, sistem GCG yang efisien diperlukan untuk keberhasilan dan stabilitas perusahaan.

\section{Manajemen Laba (Earning Management)}

Manajemen laba dikenal sebagai taktik yang dipergunakan oleh manajer untuk memanipulasi pendapatan tanpa melanggar hukum. Strategi ini berasal dari peraturan dan kebijakan akuntansi dalam menyusun laporan keuangan. Tindakan ini dapat menyebabkan kualitas pelaporan yang tidak baik dalam laporan keuangan dan menyebabkan pemegang saham membuat keputusan yang salah. Praktek manajemen laba terjadi tanpa melanggar kebijakan akuntansi (Chandrasegaram et al., 2013). Manajemen laba akan menyesatkan persepsi stakeholders mengenai kinerja keuangan yang sebenarnya pada perusahaan, dan menyebabkan pelaporan angka-angka akuntansi berbeda yang akan mengarah pada pengambilan keputusan yang keliru (Healy \& Wahlen, 1999).

\section{Pengembangan Hipotesis}

Salah satu elemen terpenting dalam mengembangkan pasar serta menarik investor untuk perusahaan dan bagi perekonomian secara keseluruhan adalah GCG. Menjelaskan dan mempublikasikan standar GCG yang baik sangat penting jika perusahaan ingin menarik modal investasi, mengurangi risiko dan mengembangkan kinerja perusahaan (Ahmed \& Hamdan, 2015). Hasil studi yang dilakukan oleh Ahmed \& Hamdan (2015), Mashitoh \& Irma (2013) dan Fuzi et al. (2016) menemukan bahwa penerapan GCG dengan baik pada perusahaan akan mempengaruhi secara signifikan dan positif atas kinerja perusahaan. Tetapi, ada hasil berbeda pada penelitian Sheikh et al. (2013) dan Vintilă et al. (2018) yang menemukan bahwa GCG mempengaruhi secara signifikan negatif kinerja perusahaan. Studi lebih lanjut yang dilakukan oleh Peters \& Bagshaw (2014) dan Coskun \& Sayilit (2012) menghasilkan bahwa GCG tidak memiliki pengaruh signifikan atas kinerja perusahaan. Dengan uraian di atas, hipotesis yang diajukan adalah:

H1: GCG yang baik memiliki hubungan signifikan dan positif dengan kinerja perusahaan

Teori CSR fokus pada partisipasi yang dilakukan perusahaan pada lingkungan dan komunitas sekitar. Ini menunjukkan bahwa perusahaan pada umumnya selain memperhatikan dirinya sendiri dalam menghasilkan laba namun juga memiliki tanggung jawab kepada masyarakat dan memastikan bahwa ia menjaga hubungan yang baik dengan customers. Dengan demikian, sangat penting bagi perusahaan untuk menjaga komitmennya dalam berperilaku baik dan berkontribusi pada pengembangan ekonomi serta menumbuhkan kualitas hidup karyawan dan masyarakat sekitarnya (Mwangi \& Oyenje, 2013). Hubungan antara CSR dan kinerja perusahaan timbul terutama dilihat pada tiga sudut pandang berikut: korelasi positif, korelasi yang negatif dan yang sama sekali tidak ada korelasi. Chen \& Wang (2011), Palmer (2012) dan Rajput et al. (2012) menyoroti 
argumen pertama dimana CSR akan meningkatkan kinerja perusahaan. Ketika perusahaan berkontribusi kepada masyarakat, pelanggan akan membeli produk perusahaan lebih banyak sehingga penjualan perusahaan akan meningkat. Namun demikian, penelitian sebelumnya yang telah dilakukan mengungkapkan bahwa ada hubungan negatif (Becchetti \& Ciciretti, 2011) atau tidak ada hubungan (Mwangi \& Oyenje, 2013 dan Aras \& Crowther, 2009) dari CSR ke kinerja perusahaan. Hipotesis berikut ini berpendapat:

H2: CSR memiliki pengaruh signifikan positif terhadap kinerja perusahaan

Johari et al. (2009) meneliti hubungan manajemen laba yang dipengaruhi oleh independensi dewan, kompetensi dan kepemilikan di perusahaan Malaysia. Penelitian yang dihasilkan menyatakan bahwa GCG yang baik mempunyai pengaruh signifikan negatif terhadap manajemen laba. Menurut Klein (2002), mekanisme efektif utama dalam memantau proses akuntansi adalah dewan independen. Temuan ini selaras dengan penelitian yang dihasilkan oleh Lee et al. (2012) dan Uwuigbe et al. (2015). Tetapi ada beberapa hasil penelitian yang yang tidak mendukung temuan di atas (Hermiyetti \& Manik, 2013 dan Nuryana \& Surjandari, 2019). Mereka menyimpulkan bahwa GCG yang baik tidak memiliki hubungan dengan manajemen laba. Mekanisme GCG hanya dianggap berfungsi sebagai platform untuk memenuhi regulasi dan undang-undang, sehingga pelaksanaan GCG menjadi tidak optimal dan tidak efektif pada manajemen kontrol perusahaan (Hermiyetti \& Manik, 2013). Dari uraian diatas, hipotesis nya adalah:

H3: GCG yang baik berpengaruh signifikan negatif terhadap manajemen laba

Untuk menjaga dan mempertahankan kinerja dari pantauan stakeholders, yang mungkin mempengaruhi penilaian terhadap pimpinan perusahaan serta menjaga nama baik perusahaan, para manajer memiliki kepentingan mereka sendiri untuk memberikan kompensasi kepada para stakeholders melalui CSR. Sebagai contoh, manajer yang melakukan manipulasi laba akan memainkan peran ramah-sosial dan menganggap bahwa kegiatan CSR sebagai alat yang baik untuk mendapatkan dukungan dari stakeholders. Beberapa penelitian yang dihasilkan oleh Scholtens \& Kang (2013), Prior et al. (2008) dan Kim \& Yi (2006) memaparkan bahwa CSR mempunyai pengaruh signifikan negatif terhadap manajemen laba. Perusahaan yang melakukan sedikit praktik manajemen laba memiliki motif lebih rendah untuk mencari perhatian publik dengan mempromosikan kegiatan CSR (Prior et al., 2008). Sedangkan perusahaan yang berpartisipasi dalam kegiatan CSR dapat membatasi manajemen laba sehingga memiliki transparansi dan laporan keuangan yang dipercaya oleh investor dibandingkan perusahaan yang tidak menjalankan CSR. Hipotesis berikut adalah:

H4: CSR memiliki pengaruh signifikan negatif terhadap manajemen laba

Penelitian yang dihasilkan oleh Cornett et al. (2009) dan Awais Akram et al. (2015) menyatakan manajemen laba mempunyai pengaruh yang negatif terhadap kinerja perusahaan. Ini meng-indikasikan bahwa perusahaan yang dapat menghasilkan laba lebih besar akan kurang terlibat dalam manajemen laba. Studi lebih lanjut yang dilakukan oleh Nuryana \& Surjandari (2019) bertentangan dengan temuan sebelumnya yang menyatakan manajemen laba tidak mempunyai pengaruh signifikan atas kinerja perusahaan. Sementara itu, Assih et al. (2005) mengemukakan bahwa manajemen laba mempunyai hubungan signifikan dan positif terhadap kinerja perusahaan. Dengan demikian, hipotesis berikut adalah:

H5: Manajemen laba berpengaruh signifikan positif terhadap kinerja perusahaan

Kinerja perusahaan dalam suatu perusahaan dapat ditingkatkan dengan GCG, mengurangi risiko yang dibuat direksi yang hanya menguntungkan kepentingan mereka, dan secara umum GCG dapat menumbuhkan kepercayaan pemegang saham untuk melakukan investasi tambahan yang 
selanjutnya akan mempengaruhi kinerja perusahaan (Mahrani \& Soewarno, 2018). Adanya GCG dan auditor independen dapat memberikan pemantauan yang baik agar tidak terjadi kecurangan dalam pelaporan keuangan dan membatasi tindakan rekayasa yang kemungkinan dilakukan seperti manajemen laba. Perusahaan cenderung akan meningkatkan kegiatan operasional untuk kepentingan pribadi manajernya sehingga mereka bisa diberikan insentif lebih besar lagi dari laba yang diperoleh perusahaan. Oleh karena itu, perusahaan akan termotivasi untuk menyelidiki kegiatan operasional dan mendeteksi manajemen laba. Studi yang telah dilaksanakan oleh Ching et al. (2015) menemukan indikasi bahwa manajemen laba memiliki peran mediasi antara GCG dengan kinerja perusahaan dan manajemen laba dapat menciptakan hubungan yang lebih kuat antara GCG dan kinerja perusahaan. Maka hipotesis yang diajukan berikut ini adalah:

\section{H6: GCG mempengaruhi kinerja perusahaan melalui manajemen laba sebagai variabel mediasi}

Kehadiran kegiatan CSR membantu perusahaan untuk beroperasi dengan tenang dan mendapatkan dukungan dari masyarakat. Transparansi laporan keuangan dapat dicapai dengan pengungkapan CSR yang mana dapat membuat manajer untuk menghindari praktik manajemen laba. Oleh karena itu, moral karyawan akan meningkat melalui CSR dan menciptakan hubungan baik dengan investor. Kepercayaan investor dapat diperoleh karena praktik manajemen laba yang rendah dan hal ini akan menuju pada peningkatan kinerja perusahaan. Penelitian yang telah dilakukan sebelumnya memaparkan bahwa hubungan antara CSR dan kinerja perusahaan dapat di mediasi oleh manajemen laba (Liu et al., 2017 dan Sial et al., 2018). Oleh karena itu, diajukan hipotesis berikut ini:

H7: CSR mempengaruhi kinerja perusahaan melalui manajemen laba sebagai variabel mediasi.

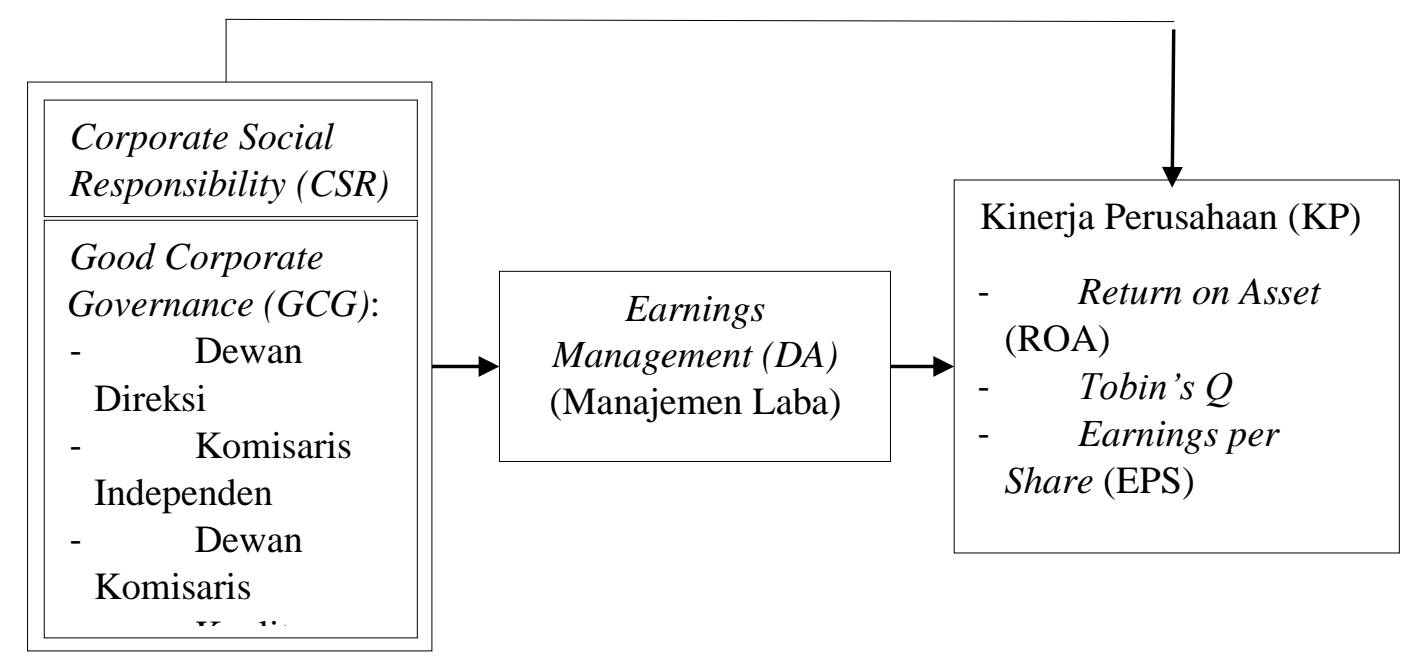

Sumber: Diolah untuk Keperluan Penelitian

Gambar 1. Kerangka Pemikiran

\section{METODE PENELITIAN}

Penelitian ini adalah penelitian kuantitatif dan diklasifikasikan sebagai penelitian dasar karena dikembangkan dari teori sebelumnya yang sudah ada dan menjelaskan apakah hipotesis cocok dengan teori atau tidak. Analisis komparatif kausal digunakan dalam penelitian ini karena penelitian perlu 
membuktikan apakah ada sebab dan akibat dari GCG, CSR, manajemen laba, serta kinerja perusahaan. Hanya perusahaan keluarga yang listed di Bursa Efek Indonesia yang dijadikan sampel penelitian ini untuk periode 2014-2018. Sampel dipilih dengan purposive sampling dan terpilih sebanyak 116 perusahaan keluarga yang memenuhi kriteria. Dalam melakukan analisis pada model penelitian dan pengujian hipotesis, digunakan model partial least square (PLS) berikut dengan outer model dan inner model (Ghazali \& Latan, 2015). Pada outer model akan dilakukan 3 pengujian, yakni convergence validity, discriminant validity dan composite reliability. Inner model akan menguji hubungan antar variable dengan menggunakan $\mathrm{R}^{2}$, dan meliputi pengujian coefficient determinant $\left(\mathrm{R}^{2}\right)$, path coefficients dan indirect

effect.

Tabel 1 Operasional Variabel Penelitian

\begin{tabular}{|c|c|}
\hline Variabel & Pengukuran \\
\hline $\begin{array}{l}\text { Dependen: } \\
\text { - Return on Assets (ROA) } \\
\text { - Tobin's } Q\end{array}$ & $\begin{array}{l}\frac{\text { Net Profit }}{\text { Total Asset }} \\
\text { Market Value Equity + Total Liabilities }\end{array}$ \\
\hline - Earnings per Share (EPS) & $\begin{array}{c}\text { Total Asset } \\
\text { Net Profit }- \text { Dividend paid for Preferred Stock }\end{array}$ \\
\hline $\begin{array}{l}\text { Independen: } \\
\text { Corporate Social } \\
\text { Responsibility }(\mathrm{CSR})\end{array}$ & Outstanding CS \\
\hline $\begin{array}{l}\text { Good Corporate Governance } \\
\text { (GCG) } \\
\text { - Dewan Direksi } \\
\text { - Komisaris Independen } \\
\text { - Dewan Komisaris } \\
\text { - Kualitas Audit }\end{array}$ & $\begin{array}{l}\text { ISO 26000: Guidance Standard on Social Responsibility, } \\
\text { dengan } 37 \text { items } \\
\text { Jumlah anggota Dewan Direksí } \\
\text { Jumlah Komisaris Independen }\end{array}$ \\
\hline $\begin{array}{l}\text { Mediasi: } \\
\text { Manajemen Laba } \\
\text { (Earnings Management) }\end{array}$ & $\begin{array}{l}\text { Total Komisaris } \\
\text { Jumlah anggota Dewan Komisaris } \\
\text { Variabel Dummy. } \\
\text { 1: Jika diaudit oleh KAP Big Four } \\
\text { 0: Jika tidak diaudit oleh KAP Big Four } \\
\text { DAC } C_{i t}=\left[\frac{T A C}{A_{i t-1}}\right]-\text { NDAC } C_{i, t} \\
\text { (Discretionary Accruals Modified Jones Model) }\end{array}$ \\
\hline
\end{tabular}

PEMBAHASAN

Perusahaan keluarga yang listed di Bursa Efek Indonesia berjumlah 120 perusahaan, tetapi hanya 116 dari 120 perusahaan yang dapat memenuhi kriteria pada penelitian ini.
Sehingga terdapat 580 data observasi untuk 5 tahun penelitian. Setelah dikurangi data oulier sebanyak 37 , maka yang selanjutnya dipakai pada penelitian ini adalah 543 data observasi. 
Tabel 2 Statistik Deskriptif

\begin{tabular}{|l|c|c|c|c|c|}
\hline \multicolumn{1}{|c|}{ Variables } & $\mathbf{N}$ & Min & Max & Mean & St. Dev. \\
\hline Return on Assets ROA) & 543 & -.6003 & .4556 & .0278 & .0941 \\
\hline Tobin's Q & 543 & .2835 & 12.9624 & 1.5660 & 1.6098 \\
\hline $\begin{array}{l}\text { Earnings per Share } \\
\text { (EPS) }\end{array}$ & 543 & -2403.57 & 4050.2659 & 150.9822 & 499.5203 \\
\hline Manajemen Laba & 543 & -.5363 & .6724 & .0684 & .1145 \\
\hline $\begin{array}{l}\text { Corporate Social } \\
\text { Responsibility CSR) }\end{array}$ & 543 & .0270 & .8649 & .3553 & .1724 \\
\hline Dewan Direksi & 543 & 2 & 10 & 4.5000 & 1.8820 \\
\hline Komisaris Independen & 543 & .1429 & .6670 & .4127 & .1060 \\
\hline Dewan Komisaris & 543 & 2 & 8 & 3.9800 & 1.3500 \\
\hline
\end{tabular}

Sumber: Data BEI diolah, 2018

Pada Tabel 2, rata rata ROA adalah 2,78\% dengan standar devisasi sebesar 9,41\%. Ini menjelaskan bahwa perusahaan keluarga cukup efisien memanfaatkan asset perusahaan untuk menghasilkan laba. Tobin's Q memiliki mean sebesar 1,5660. Ini menunjukkan bahwa secara umum, manajemen berhasil mengelola aktiva perusahaan dengan baik dan memiliki daya tarik untuk para investor. Rata rata EPS adalah 150,9822. Indikator ini cukup baik untuk perusahaan keluarga yang menunjukkan laba per saham perusahaan keluarga adalah Rp. 151.

Pada perusahaan keluarga, rata-rata nilai dewan direksi adalah 4,5 yang berarti total anggota dewan direksi di setiap perusahaan adalah 4 atau 5 orang, sedangkan anggota dewan komisaris berjumlah 4 orang. Untuk komisaris independen, rata-rata persentase nya adalah $41 \%$. Ini meng indikasikan bahwa secara keseluruhan, perusahaan keluarga pada BEI telah memenuhi persyaratan bahwa perusahaan wajib mempunyai paling sedikit empat orang anggota dewan direksi dan komisaris (Undang-Undang Republik Indonesia Nomor 40 Tahun 2007 Tentang Perseroan Terbatas, 2007) dan memiliki tidak kurang dari $30 \%$ anggota komisaris independen dari seluruh anggota dewan komisaris (Keputusan Direksi PT Bursa Efek Jakarta Nomor : Kep-305/BEJ/07-2004, 2004). CSR yang menggunakan 37 item pada ISO 26000, mempunyai nilai rata-rata 0.3552 yang artinya perusahaan keluarga pada periode 2014-2018 rata-rata mengungkapkan
$35,52 \%$ CSR. Dengan nilai tertinggi 0,8649 dan terrendah 0,0270 , CSR memiliki nilai standar deviasi 0.1724 dari keseluruhan ratarata. Angka minimum manajemen laba adalah $-0,5363$ dan nilai maksimun adalah 0,6724 , serta angka mean sebesar 0,0684. Angka manajemen laba yang mendekati angka 0 menggambarkan bahwa perusahaan keluarga cenderung melakukan praktik manupulasi laba dalam membukukan dan menyusun laporan keuangan, salah satunya yakni dengan income smoothing atau perataan laba.

Tabel 3 Statistik Deskriptif Variabel Dummy

\begin{tabular}{|l|c|c|c|}
\hline & N & Percent & $\begin{array}{c}\text { Cum. } \\
\text { Percent }\end{array}$ \\
\hline $\begin{array}{l}\text { Non-Big Four } \\
\text { Auditor }\end{array}$ & 358 & $65.9 \%$ & 65.9 \\
\hline $\begin{array}{l}\text { Big Four } \\
\text { Auditor }\end{array}$ & 185 & $34.1 \%$ & 100 \\
\hline
\end{tabular}

Sumber: Data BEI diolah, 2018

Tabel 3 diatas menyajikan informasi bahwa dari 543 data terdapat 358 perusahaan yang diaudit Kantor Akuntan Publik (KAP) non-big four berbanding 185 perusahaan yang diaudit KAP big-four. Hal ini meng-indikasikan bahwa lebih sedikit perusahaan keluarga di Indonesia yang memakai jasa KAP big four.

Hasil convergence validity test menunjukkan proksi yang memenuhi validitas konvergensi adalah Kualitas Audit, Dewan Direksi, Dewan Komisaris, Corporate Social Responsibility (CSR), Manajemen Laba, Return on Asset (ROA) dan Earning per Share (EPS) yang masing-masing proksi lebih besar dari nilai 0,7. Komisaris Independen dan Tobin's $\mathbf{Q}$ tidak memenuhi kriteria validitas karena 
masing-masing nilai adalah 0,041 dan 0,362 , yang mana lebih rendah dari 0,4 . Untuk discriminant validity test, semua proxy memenuhi kriteria validitas diskriminan. Sedangkan pada composite reliability test diiperoleh hasil bahwa setiap konstruk telah memenuhi batas yang disyaratkan, yaitu lebih dari 0,6-0,7 (Hair et al., 2011).

Dari hasil $R$ square test yang terlihat pada Tabel 4, manajemen laba dan kinerja perusahaan masing-masing mempunyai nilai $\mathrm{R}^{2}$ sebesar 0,018 dan 0,147 . Ini menjelaskan bahwa variabel manajemen laba bisa dijelaskan sebesar 1,8\% oleh GCG dan CSR, sedangkan kinerja perusahaan dapat dijelaskan $14,7 \%$ oleh GCG, CSR dan manajemen laba. Rendahnya hasil $\mathrm{R}^{2}$ dalam manajemen laba dan kinerja keuangan dikarenakan oleh variabel lainnya yang pada penelitian ini tidak digunakan dan di luar ruang lingkup penelitian. Tabel 4 juga menggambarkan bahwa nilai $p$ GCG dan CSR tidak berdampak signifikan terhadap manajemen laba. Sementara itu, GCG, CSR serta manajemen laba mempunyai pengaruh yang signifikan terhadap kinerja perusahaan.

Tabel 4 Hasil Uji $R$ square

\begin{tabular}{|l|c|c|c|}
\hline $\begin{array}{l}\text { Dependent } \\
\text { Variable }\end{array}$ & $\begin{array}{c}\text { Sample } \\
\text { Mean }\end{array}$ & $\begin{array}{c}\mathbf{P} \\
\text { Values }\end{array}$ & Desc. \\
\hline DA & 0.018 & 0.348 & insignificant \\
\hline KP & 0.147 & 0.000 & Significant \\
\hline
\end{tabular}

Sumber: Data Diolah, 2018

Dampak dari variabel laten ke variabel laten lainnya dapat dilihat dari hasil path coefficient (koefisien jalur). Jika nilai $\mathrm{p}$ probabilitas menunjukkan angka lebih keci dari 0,05 dan $t$ statistic lebih besar dari 1,96, maka variabel independen memiliki dampak signifikan terhadap variabel dependen. Hasil path cofficient test ditunjukkan pada Tabel 5 dibawah ini.

Tabel 5 Hasil Uji Path Coefficient

\begin{tabular}{|l|c|c|c|c|l|}
\hline \multicolumn{1}{|c|}{ Variables } & Sample Mean & t-Statistic & p-Value & Description & \\
\hline GCG $\rightarrow$ FP & 0.275 & 6.389 & 0.000 & Significant $(+)$ & \\
\hline CSR $\rightarrow$ FP & 0.118 & 3.568 & 0.000 & Significant $(+)$ & \\
\hline GCG $\rightarrow$ DA & -0.112 & 2.255 & 0.025 & Significant (-) & \\
\hline CSR $\rightarrow$ DA & -0.007 & 0.250 & 0.803 & Insignificant $(-)$ & \\
\hline DA $\rightarrow$ FP & 0.229 & 3.680 & 0.000 & Significant $(+)$ & \\
\hline
\end{tabular}

Sumber: Data Diolah, 2018

Hasil pada Tabel 6 menunjukkan bahwa variabel mediasi yaitu manajemen laba diukur dengan discretionary accrual (DA) dapat memediasi hubungan antara GCG dan kinerja perusahaan. Hal ini ditunjukkan oleh $t$ statistic sebesar 2,101 yang mana lebih besar dari 1,96 dan nilai $p$ 0,039 yang kurang dari 0,05 . Namun manajemen laba tidak memiliki peran mediasi untuk hubungan antara CSR dan kinerja perusahaan. Ini dibuktikan dengan t-statistic sebesar 0,241 (kurang dari 1,96) dan nilai $p$ yaitu 0,798 (lebih dari 0,05 ).

Tabel 6 Hasil Uji Indirect Effects

\begin{tabular}{|c|c|c|c|c|}
\hline Variables & Sample Mean & t-Statistic & p-value & Hypothesis \\
\hline GCG $\rightarrow$ DA $\rightarrow$ FP & -0.019 & 2.101 & 0.039 & Significant (-) \\
\hline $\mathrm{CSR} \rightarrow$ DA $\rightarrow$ FP & -0.002 & 0.241 & 0.798 & Insignificant (-) \\
\hline
\end{tabular}

Sumber: Data Diolah, 2018

\section{PENUTUP}

Dari hasil yang diperoleh, penelitian ini menjelaskan bahwa GCG memiliki dampak signifikan positif terhadap kinerja perusahaan. Peran dewan komisaris sangat baik mengawasi tindakan manajemen perusahaan dan memantau fungsi dewan direksi. Selain itu, perusahaan keluarga yang diaudit oleh KAP big four mempunyai 
pengaruh signifikan positif terhadap kinerja perusahaan. Ini menjelaskan bahwa dengan reputasi yang baik, KAP dapat memberikan saran yang tepat untuk kondisi perusahaan dalam meningkatkan kinerja perusahaan. CSR juga mempunyai pengaruhi signifikan dan positif terhadap kinerja perusahaan. Dengan implementasi CSR yang konsisten, memengaruhi keinginan pelanggan untuk membeli lebih banyak produk dari perusahaan, mendapatkan kepuasan pelanggan dan meningkatkan citra perusahaan yang bermuara pada hasil kinerja perusahaan yang baik. GCG berpengaruh signifikan negatif terhadap manajemen laba. GCG dapat membantu meningkatkan kinerja perusahaan karena dewan komisaris dan kualitas audit dapat secara efektif mengurangi perilaku manajer untuk memanipulasi laba. KAP big four sebagai auditor profesional dapat meningkatkan kesadaran manajer bahwa memanipulasi laporan keuangan akan terungkap dan terdeteksi oleh auditor. CSR tidak mempunyai pengaruh terhadap manajemen laba. CSR bukan alat yang digunakan oleh pimpinan perusahaan untuk menutupi perilaku tidak etis dalam memanipulasi laba. Adanya kegiatan CSR adalah untuk memenuhi regulasi dan tidak mempunyai hubungan yang signifikan dengan praktik manajemen laba. Manajer pada perusahaan keluarga mengambil keuntungan dengan memanipulasi laporan keuangan menjadi kinerja yang lebih baik hanya untuk memenuhi kepentingan pribadi dan menarik investor sehingga perusahaan dapat bertahan hidup meskipun kualitas laporan kinerja tidak akurat. Manajemen laba dapat memediasi hubungan antara GCG dan kinerja perusahaan. GCG telah berkontribusi besar dalam mengurangi kemungkinan memaksimalkan laba dengan cara yang tidak baik. Namun manajemen laba gagal memediasi hubungan antara CSR dan kinerja perusahaan untuk perusahaan milik keluarga.

Untuk penelitian selanjutnya, disarankan agar membandingkan data penelitian di Indonesia dan negara lain dan memperluas jangkauan sampel serta membandingkan antara perusahaan keluarga dan perusahaan yang bukan dimiliki keluarga. Diharapkan variabel independen ditambah untuk mencerminkan mekanisme GCG yang mengarah pada model fit goodness yang lebih tinggi.

\section{REFERENSI}

Ahmed, E., \& Hamdan, A. (2015). The Impact of Corporate Governance on Firm Performance: Evidence from Bahrain Stock Exchange. European Journal of Business and Innovation Research, 3(5), 25-48. https://doi.org/10.1017/CBO97811074 15324.004

Aras, G., \& Crowther, D. (2009). Corporate Sustainability Reporting: A Study in Disingenuity? Journal of Business Ethics, 87, 279-288. https://doi.org/10.1007/s10551-0089806-0

Assih, P., Hastuti, A. W., \& Parawiyati. (2005). Pengaruh Manajemen Laba pada Nilai dan Kinerja Perusahaan. Jurnal Akuntansi Dan Keuangan Indonesia, 2(2), 125-144.

Awais Akram, M., Imran Hunjra, A., Butt, S., \& Ijaz, I. (2015). Earnings management and organizational performance: Pakistan VS India. Basic Research Journal of Business Management and Accounts, 4(9), 211220.

Becchetti, L., \& Ciciretti, R. (2011). Corporate Social Responsibility and Stock Market Performance. SSRN Electronic Journal, 2(7). https://doi.org/10.2139/ssrn.897499

Chandrasegaram, R., Rahimansa, M. R., Rahman, S. K. A., Abdullah, S., \& Mat, N. N. (2013). Impact of Audit Committee Characteristics on Earnings Management in Malaysian Public Listed Companies. International Journal of Finance and Accounting, 2(2), 114-119. https://doi.org/10.5923/j.ijfa.20130202. 11 
Chen, H., \& Wang, X. (2011). Corporate social responsibility and corporate financial performance in China: An empirical research from Chinese firms. Corporate Governance, 11(4), 361370.

https://doi.org/10.1108/147207011111 59217

Ching, C. P., Teh, B. H., San, O. T., \& Hoe, H. Y. (2015). The relationship among audit quality, earnings management, and financial performance of Malaysian public listed companies. International Journal of Economics and Management, 9(1), 211-229.

Cornett, M. M., McNutt, J. J., \& Tehranian, H. (2009). Corporate governance and earnings management at large U.S. bank holding companies. Journal of Corporate Finance, 15(4), 412-430. https://doi.org/10.1016/j.jcorpfin.2009. 04.003

Coskun, M., \& Sayilit, O. (2012). Relationship Between Corporate Governanceand Financial Performance of Turkish Companies. International Journal of Business and Social Science, 3(14).

Deegan, C., Rankin, M., \& Tobin, J. (2002). An examination of the corporate social and environmental disclosures of BHP from 1983-1997: A test of legitimacy theory. Accounting, Auditing \& Accountability Journal, 15(3), 312343.

https://doi.org/10.1108/095135702104 35861

Fuzi, S. F. S., Halim, S. A. A., \& Julizaerma, M. K. (2016). Board Independence and Firm Performance. Procedia Economics and Finance, 37(16), 460-465. https://doi.org/10.1016/s22125671(16)30152-6

Ghazali, I., \& Latan, H. (2015). Partial least squares konsep, teknik dan aplikasi menggunakan program SmartPLS 3.0 untuk penelitian empiris. Semarang Badan Penerbit Universitas Diponegoro.

Hair, J. F., Ringle, C. M., \& Sarstedt, M. (2011). PLS-SEM: Indeed a silver bullet. Journal of Marketing Theory and Practice, 19(2), 139-152. https://doi.org/10.2753/MTP10696679190202

Harrison, J. S., \& Wicks, A. C. (2013). Stakeholder Theory, Value, and Firm Performance. Business Ethics Quarterly, 23(1), 97-124. https://doi.org/10.5840/beq20132314

Healy, P. M., \& Wahlen, J. M. (1999). A Review Of The Earnings Management Literature And Its Implications For Standard Setting. Accounting Horizons, 13 (4)(November), 365-383. https://doi.org/10.2139/ssrn.156445

Hermiyetti, H., \& Manik, E. N. (2013). The Influence of Good Corporate Governance Mechanism on Earnings Management: Empirical Study in Indonesian Stock Exchange Listed Company for Periods of 2006-2010. Indonesian Capital Market Review, 5(1), 52-63. https://doi.org/10.21002/icmr.v5i1.158 3

Jensen, M. C., \& Meckling, W. H. (1976). Theory of The Firm: Managerial Behavior, Agency Costs and Ownership Structure. Journal of Financial Economics, 3(4), 305-360. https://doi.org/10.1177/001872671881 2602

Johari, N. H., Saleh, N. M., Jaffar, R., \& Hassan, M. S. (2009). The influence of board independence, competency and ownership on earnings management in Malaysia. International Journal of Economics and Management, 2(2), 281-306.

Peraturan Nomor I-A Tentang Pencatatan Saham Dan Efek Bersifat Ekuitas Selain Saham Yang Diterbitkan Oleh Perusahaan Tercatat, 1 (2004).

Kim, J. B., \& Yi, C. H. (2006). Structure de propriété, affiliation à des groupes d'affaires, statut quant à la cotation boursière et gestion du résultat: La situation coréenne. Contemporary Accounting Research, 23(2), 427-464. https://doi.org/10.1506/7T5B-72FVMHJV-E697

Klein, A. (2002). Audit committee, board of 
director characteristics, and earnings management. Journal of Accounting and Economics, 33(3), 375-400. https://doi.org/10.1016/S01654101(02)00059-9

Kompas. (2019, July 21). Imbas Perang Dagang, Lebih dari 50 Perusahaan Asing Kabur dari China. Kompas.Com. https://money.kompas.com/read/2019/ 07/21/063316426/imbas-perangdagang-lebih-dari-50-perusahaanasing-kabur-dari-china.

Lee, T.-H., Ku, C., Chen, H., \& Chen, J.-F. (2012). A Study of Corporate Governance Factors and Earnings Management Behaviors of Taiwan Public Companies. International Journal of Business, Humanities and Technology, 2(5), 79-88.

Liu, M., Shi, Y., Wilson, C., \& Wu, Z. (2017). Does family involvement explain why corporate social responsibility affects earnings management? Journal of Business Research, 75(February 2019), 8-16. https://doi.org/10.1016/j.jbusres.2017.0 2.001

Mahrani, M., \& Soewarno, N. (2018). The effect of good corporate governance mechanism and corporate social responsibility on financial performance with earnings management as mediating variable. Asian Journal of Accounting Research, 3(1), 41-60. https://doi.org/10.1108/ajar-06-20180008

Mashitoh, A. H., \& Irma, B. (2013). The Influence Of Corporate Governance Implementation Toward Bank Performance (Empirical Study on Banks Listed in Indonesia Stock Exchange ). International Journal on Economics and Social Sciences, 1(1), 25-35.

Mwangi, C. I., \& Oyenje, J. J. (2013). The Relationship between Corporate Social Responsibility Practices and Financial Performance of Firms in the Manufacturing , Construction and Allied Sector of the Nairobi Securities
Exchange Cyrus Iraya Mwangi Lecturer Department of Finance and Accounting. International Journal of Business, Humanities and Technology, 3(2), 81-90.

Nuryana, Y., \& Surjandari, D. A. (2019). The Effect of Good CorporateNuryana, Y., \& Surjandari, D. A. (2019). The Effect of Good Corporate Governance. Jurnal Ekonomi, 19(1), 26-39. Governance. Jurnal Ekonomi, 19(1), 26-39.

Palmer, H. J. (2012). Corporate Social Responsibility and Financial Performance: Does it Pay to Be Good? CMC Senior Theses, 1-72. http://scholarship.claremont.edu/cmc_t heses/529\%0Ahttp://scholarship.clare mont.edu/cmc_theses/529\%0AThis

Parmar, B. L., Freeman, R. E., Harrison, J. S., Wicks, A. C., Purnell, L., \& de Colle, S. (2010). Stakeholder theory: The state of the art. Academy of Management Annals, 4(1), 403-445. https://doi.org/10.1080/19416520.2010 .495581

Peters, G. T., \& Bagshaw, K. (2014). Corporate governance mechanisms and financial performance of listed firms in Nigeria: A content analysis. Global Journal of Contemporary Research in Accounting, Auditing and Business Ethics (GJCRA), 1(2), 103-128.

Prior, D., Surroca, J., \& Tribó, J. A. (2008). Are socially responsible managers really ethical? Exploring the relationship between earnings management and corporate social responsibility. Corporate Governance: An International Review, 16(3), 160177. https://doi.org/10.1111/j.14678683.2008.00678.x

Rajput, N., Batra, G., \& Pathak, R. (2012). Linking CSR and financial performance: An empirical validation. Problems and Perspectives in Management, 10(2), 42-49.

Scholtens, B., \& Kang, F. C. (2013). Corporate Social Responsibility and Earnings Management: Evidence from 
Asian Economies. Corporate Social Responsibility and Environmental Management, 20(2), 95-112. https://doi.org/10.1002/csr.1286

Sheikh, N. A., Wang, Z., \& Khan, S. (2013). The impact of internal attributes of corporate governance on firm performance: Evidence from pakistan. International Journal of Commerce and Management, 23(1), 38-55. https://doi.org/10.1108/105692113113 01420

Sial, M. S., Chunmei, Z., Khan, T., \& Nguyen, V. K. (2018). Corporate social responsibility, firm performance and the moderating effect of earnings management in Chinese firms. AsiaPacific Journal of Business Administration, 10(2-3), 184-199. https://doi.org/10.1108/APJBA-032018-0051

Undang-Undang Republik Indonesia Nomor 40 Tahun 2007 Tentang Perseroan Terbatas, (2007).

Uwuigbe, U., Ranti, U. O., \& Bernard, O. (2015). Assessment of the Effects of Firms Characteristics on Earnings Management of Listed Firms in Nigeria. Asian Economic and Financial Review, 5(2), 218-228. https://doi.org/10.18488/journal.aefr/20 15.5.2/102.2.218.228

Vintilă, G., Gherghina, Ş. C., \& Păunescu, R. A. (2018). Study of Effective Corporate Tax Rate and Its Influential Factors: Empirical Evidence from Emerging European Markets. Emerging Markets Finance and Trade, 54(3), 571-590. https://doi.org/10.1080/1540496X.201 7.1418317

Yopie, S., \& Itan, I. (2016). CEO-Family vs. CEO-Nonfamily: Who is a Better Value Creator in Family Business? Journal of Applied Management Accounting Research, 14(2), 37-46. http://search.ebscohost.com/login.aspx? direct $=$ true $\& \mathrm{db}=\mathrm{bth} \& \mathrm{AN}=120775138 \&$ site $=$ bsi-live

\section{BIODATA PENULIS}

Dr. Iskandar Itan, SE., MM menyelesaikan pendidikan S3 Doctor of Business Administration di Universiti Sains Malaysia pada tahun 2015. Dosen di Universitas Internasional Batam (Assistant Professor). Penulis tertarik melakukan penelitian di bidang keuangan perusahaan, perbankan dan Entrepreneurship 